\title{
Development of a Gas-Promoted Oil Agglomeration Process
}

\author{
Quarterly Report \\ October 1 - December 31, 1996
}

\author{
By: \\ T. D. Wheelock \\ M. Shen
}

Work Performed Under Contract No.: DE-FG22-93PC93209

For

U.S. Department of Energy

Office of Fossil Energy

Federal Energy Technology Center

P.O. Box 880

Morgantown, West Virginia 26507-0880

By

Chemical Engineering Department and

Center for Coal and the Environment

2114 Sweeney Hall

Iowa State University

Ames, Iowa 50011-2230 


\section{Disclaimer}

This report was prepared as an account of work sponsored by an agency of the United States Government. Neither the United States Government nor any agency thereof, nor any of their employees, makes any warranty, express or implied, or assumes any legal liability or responsibility for the accuracy, completeness, or usefulness of any information, apparatus, product, or process disclosed, or represents that its use would not infringe privately owned rights. Reference herein to any specific commercial product, process, or service by trade

name, trademark, manufacturer, or otherwise does not necessarily constitute or imply its endorsement, recommendation, or favoring by the United States Government or any agency thereof. The views and opinions of authors expressed herein do not necessarily state or reflect those of the United States Government or any agency thereof. 


\title{
DEVELOPMENT OF A GAS-PROMOTED OIL AGGLOMERATION PROCESS
}

\author{
Quarterly Technical Progress Report
}

October 1, 1996 - December 31, 1996

T. D. Wheelock, Principal Investigator

\begin{abstract}
Further agglomeration tests were conducted in a series of tests designed to determine the effects of various parameters on the size and structure of the agglomerates formed, the rate of agglomeration, coal recovery, and ash rejection. For this series of tests, finely ground Pittsburgh No. 8 coal has been agglomerated with i-octane in a closed mixing system with a controlled amount of air present to promote particle agglomeration. The present results provide further evidence of the role played by air. As the concentration of air in the system was increased from 4.5 to $18 \mathrm{v} / \mathrm{w} \%$ based on the weight of coal, coal recovery and ash rejection both increased. The results also show that coal recovery and ash rejection were improved by increasing agitator speed. On the other hand, coal recovery was not affected by a change in solids concentration from 20 to $30 \mathrm{w} / \mathrm{w} \%$.
\end{abstract}




\section{TABLE OF CONTENTS}

Page

Executive Summary 1

Introduction $\quad 2$

Results and Discussion $\quad 2$

$\begin{array}{ll}\text { Conclusions } & 11\end{array}$

$\begin{array}{ll}\text { References } & 12\end{array}$ 


\section{EXECUTIVE SUMMARY}

The overall purpose of this research project is to carry out the preliminary laboratory-scale development of a gas-promoted, oil agglomeration process for cleaning coal using model mixing systems. Specific objectives include determining the nature of the gas promotion mechanism, the effects of hydrodynamic factors and key parameters on process performance, and a suitable basis for size scale-up of the mixing system.

As a part of the project, numerous agglomeration tests have been conducted to determine the effects of various parameters on agglomerate size and structure, the rate of agglomeration, coal recovery and ash rejection. For the present series of tests, finely ground Pittsburgh No. 8 coal was agglomerated with i-octane in the presence of a controlled amount of air. During a batch agglomeration test, the progress of agglomeration was monitored by observing changes in agitator torque while agitator speed was held constant. The final product was recovered by screening and then analyzed to determine agglomerate size and ash content.

For this report, the effects of solids concentration, air concentration, and agitator speed on coal recovery and ash rejection were investigated. The results indicate that coal recovery and ash rejection both increased as the concentration of air in the system was raised from 4.5 to $18 \mathrm{v} / \mathrm{w} \%$ based on coal weight. Furthermore, coal recovery and ash rejection increased when agitator speed was increased from 1450 to $1750 \mathrm{rpm}$. Although an increase in solids concentration produced an increase in agglomerate size and resulted in slightly lower ash rejection, it did not affect coal recovery. 


\section{INTRODUCTION}

Results have been reported previously of a series of tests in which the agglomeration of Pittsburgh No. 8 coal with i-octane was promoted with small amounts of air (ref. 1 and 2). Some of the tests were carried out with a $7.62 \mathrm{~cm}$ diameter agitated tank using a $3.65 \mathrm{~cm}$ diameter impeller, while other tests were conducted with a $11.4 \mathrm{~cm}$ diameter tank using a $5.08 \mathrm{~cm}$ diameter impeller. The tests were conducted to determine the effects of agitation time and various system parameters on coal recovery and grade. The series of tests has been extended and the results are reported below.

\section{RESULTS AND DISCUSSION}

The agglomeration tests were conducted with coal from the Pittsburgh No. 8 Seam in Belmont County, Ohio. This coal contained 5.0\% sulfur and $28 \%$ ash on a dry basis. The preparation of this material and the equipment and procedure used for conducting agglomeration tests were described previously (ref. 3). All of the tests reported below were carried out with a $11.4 \mathrm{~cm}$ diameter agitated tank using a $5.08 \mathrm{~cm}$ diameter impeller. Pure i-octane was the agglomerate or "oil" used in each test. The particle suspension was first degassed and then dosed with i-octane. After the suspension was conditioned for $5 \mathrm{~min}$. with the agitator running at the desired test speed, a known volume of air was introduced which started the process of agglomeration. As the test continued, agitator speed was held constant while agitator torque was allowed to vary. The torque was measured and recorded continuously because it had been shown previously that changes in the torque provided an indication of the progress of agglomeration (ref. 3). The mixing tank was cooled with an ice 
Table 1. Experimental conditions and results of oil agglomeration runs with $11.4 \mathrm{~cm}$ diameter agitated tank and with $5.08 \mathrm{~cm}$ diameter impeller.

\begin{tabular}{|c|c|c|c|c|c|c|c|c|c|}
\hline $\begin{array}{l}\text { Run } \\
\text { No. }\end{array}$ & $\begin{array}{l}\text { Solids. } \\
\text { w/w\% }\end{array}$ & $\begin{array}{l}\text { Oil, } \\
\text { v/w\% }\end{array}$ & $\begin{array}{l}\text { Air, } \\
\text { v/w\% }\end{array}$ & $\begin{array}{c}\text { Speed, } \\
\text { rpm }\end{array}$ & $\begin{array}{l}\text { Time, } \\
\text { min. }\end{array}$ & $\begin{array}{r}\text { Size, } \\
\text { mm }\end{array}$ & $\begin{array}{l}\text { Ash, }{ }^{b} \\
\text { w/w\% }\end{array}$ & $\begin{array}{l}\text { Ash } \\
\text { Rej., \% }\end{array}$ & $\begin{array}{l}\text { Coal } \\
\text { Rec\% }\end{array}$ \\
\hline 72 & 30 & 20 & 4.5 & $\overline{1600}$ & $\overline{85}$ & $\overline{0.05-0.10}$ & $\overline{17.91}$ & 53.45 & 81.64 \\
\hline 73 & 30 & 20 & 4.5 & 1600 & 55 & 0.03-0.09 & 18.81 & 55.08 & 75.04 \\
\hline 74 & 30 & 20 & 4.5 & 1750 & 55 & $0.05-0.10$ & 18.16 & 57.41 & 74.22 \\
\hline 75 & 30 & 20 & 4.5 & 1450 & 55 & (flocs) & 22.48 & 93.02 & 9.21 \\
\hline 77 & 30 & 20 & 18 & 1600 & 55 & $0.08-0.12$ & 13.82 & 62.94 & 88.15 \\
\hline 78 & 30 & 20 & 18 & 1450 & 85 & $0.08-0.11$ & 14.05 & 62.93 & 85.00 \\
\hline 79 & 30 & 20 & 18 & 1750 & 85 & $0.07-0.12$ & 12.54 & 64.67 & 91.98 \\
\hline 80 & 30 & 20 & 18 & 1600 & 85 & $0.07-0.11$ & 12.97 & 64.76 & 91.91 \\
\hline 81 & 30 & 20 & 9 & 1450 & 25 & $0.04-0.06$ & 20.50 & 43.90 & 82.39 \\
\hline 82 & 20 & 30 & 9 & 1750 & 85 & $0.25-0.30$ & 8.37 & 76.50 & 96.63 \\
\hline 83 & 20 & 30 & 9 & 1600 & 85 & 0.30 & 8.42 & 77.64 & 96.63 \\
\hline
\end{tabular}

Treatment time following introduction of air. 'Size range and ash content of agglomerates. 'Ash rejected to tailings.

Coal recovery on a dry, ash-free basis.

bath to maintain the temperature of the suspension close to room temperature. At the end of a run a sample of the suspension was collected for examination with a microscope.

The range of agglomerate size was noted as well as the general shape of the agglomerates. The remaining suspension was then diluted with an equal volume of water and separated with a $250 \mathrm{~mm}$ screen. The agglomerated product and the tailings were recovered separately and then dried and weighed. The ash content of the product and tailings was determined subsequently.

The conditions employed and the results obtained in the present series of agglomeration tests or runs are presented in Table 1. The following conditions were varied amount these tests: solids concentration, oil concentration, air concentration, agitator speed, and total time of agitation after air was introduced. For each of the tests a record was obtained of the variation in agitator torque with time, as well as an indication 
of coal recovery and ash rejection. Typical results are shown in Figure 1 for three runs conducted at different agitator speeds, but otherwise similar conditions including a solids concentration of $30 \mathrm{w} / \mathrm{w} \%$, oil concentration of $20 \mathrm{v} / \mathrm{w} \%$, and air concentration of 18 $\mathrm{v} / \mathrm{w} \%$. These results are generally similar to those reported previously (ref. 2) for agglomeration of Pittsburgh No. 8 coal with 20 or $30 \mathrm{v} / \mathrm{w} \%$ i-octane and $9 \mathrm{v} / \mathrm{w} \%$ air. The most obvious difference was a much greater drop in agitator torque when $18 \mathrm{v} / \mathrm{w} \%$ air was introduced instead of $9 \mathrm{v} / \mathrm{w} \%$ air. The contrast is even greater when the results with $18 \mathrm{v} / \mathrm{w} \%$ air are compared to those with $4.5 \mathrm{v} / \mathrm{w} \%$ air shown in Figure 2. After the addition of $18 \mathrm{v} / \mathrm{w} \%$ air, the large initial drop in agitator torque was followed immediately by a sharp rise in torque signifying particle flocculation and/or agglomeration. Such was not the case with $4.5 \mathrm{v} / \mathrm{w} \%$ air where the initial drop in torque due to the addition of air was small and there was a long delay before the torque rose significantly. At the lowest agitator speed (i.e., $1450 \mathrm{rpm}$ ), the delay was especially long, and even after agitating the coal suspension for 55 min. after introducing air, the torque had not changed appreciably. Subsequent examination of the product from this run (i.e., run 75) revealed the presence of flocs and unattached particles but not agglomerates.

For the runs conducted for 85 minutes with $20 \mathrm{v} / \mathrm{w} \%$ i-octane and $18 \mathrm{v} / \mathrm{w} \%$ air, the effect of agitator speed on coal recovery and ash rejection is indicated by Figure 3 . Both increased slightly as agitator speed was raised from 1450 to $1600 \mathrm{rpm}$ and were not affected by a further increase in agitator speed. At either 1600 or $1750 \mathrm{rpm}$, approximately $92 \%$ of the coal on a dry, ash-free basis was recovered and approximately $65 \%$ of the ash was rejected. 


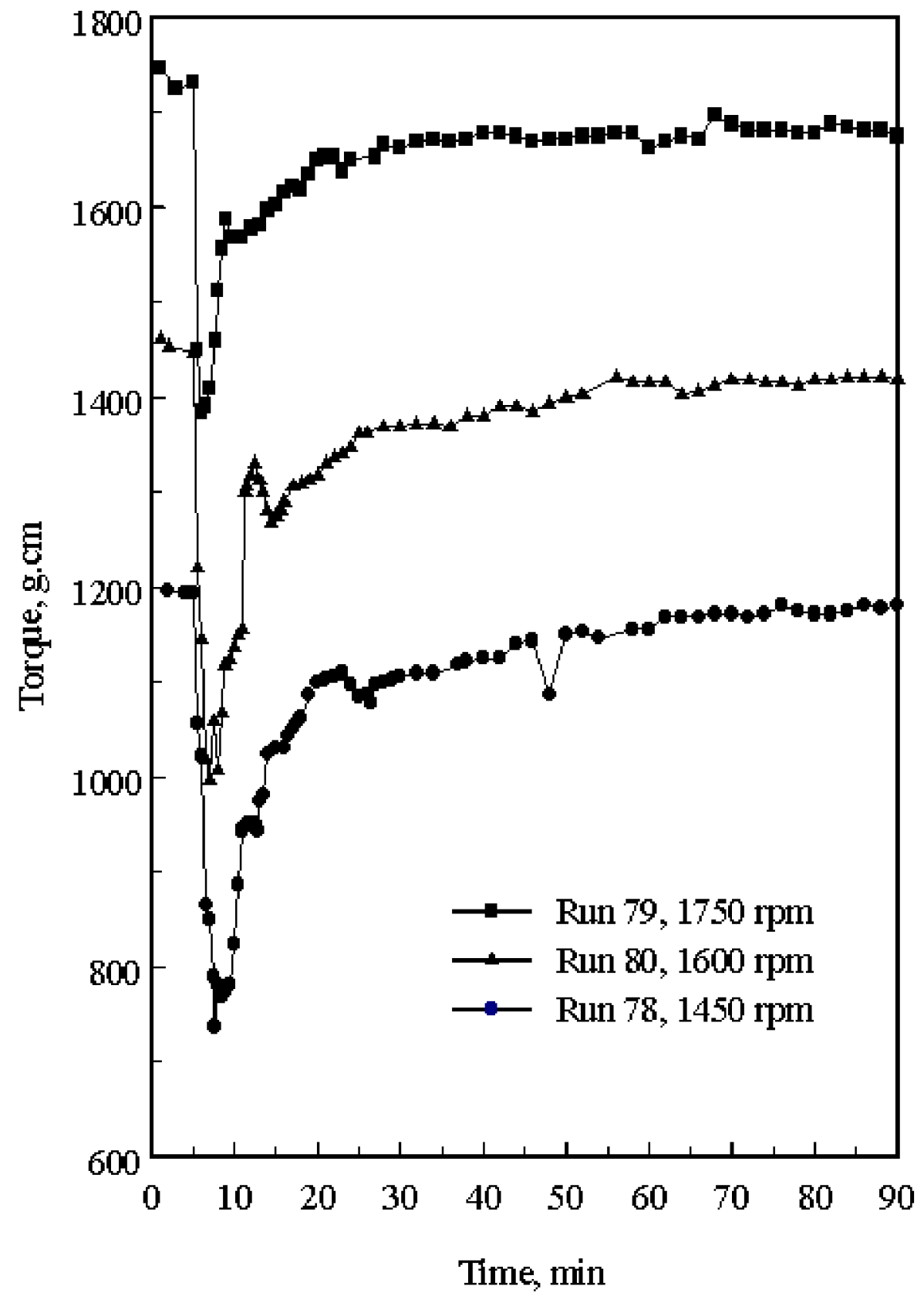

Figure 1. Results of three runs conducted with $30 \mathrm{w} / \mathrm{w} \%$ solids, $20 \mathrm{v} / \mathrm{w} \%$ oil, 18 $\mathrm{v} / \mathrm{w} \%$ air, and different agitator speeds in $11.4 \mathrm{~cm}$ diameter tank. 


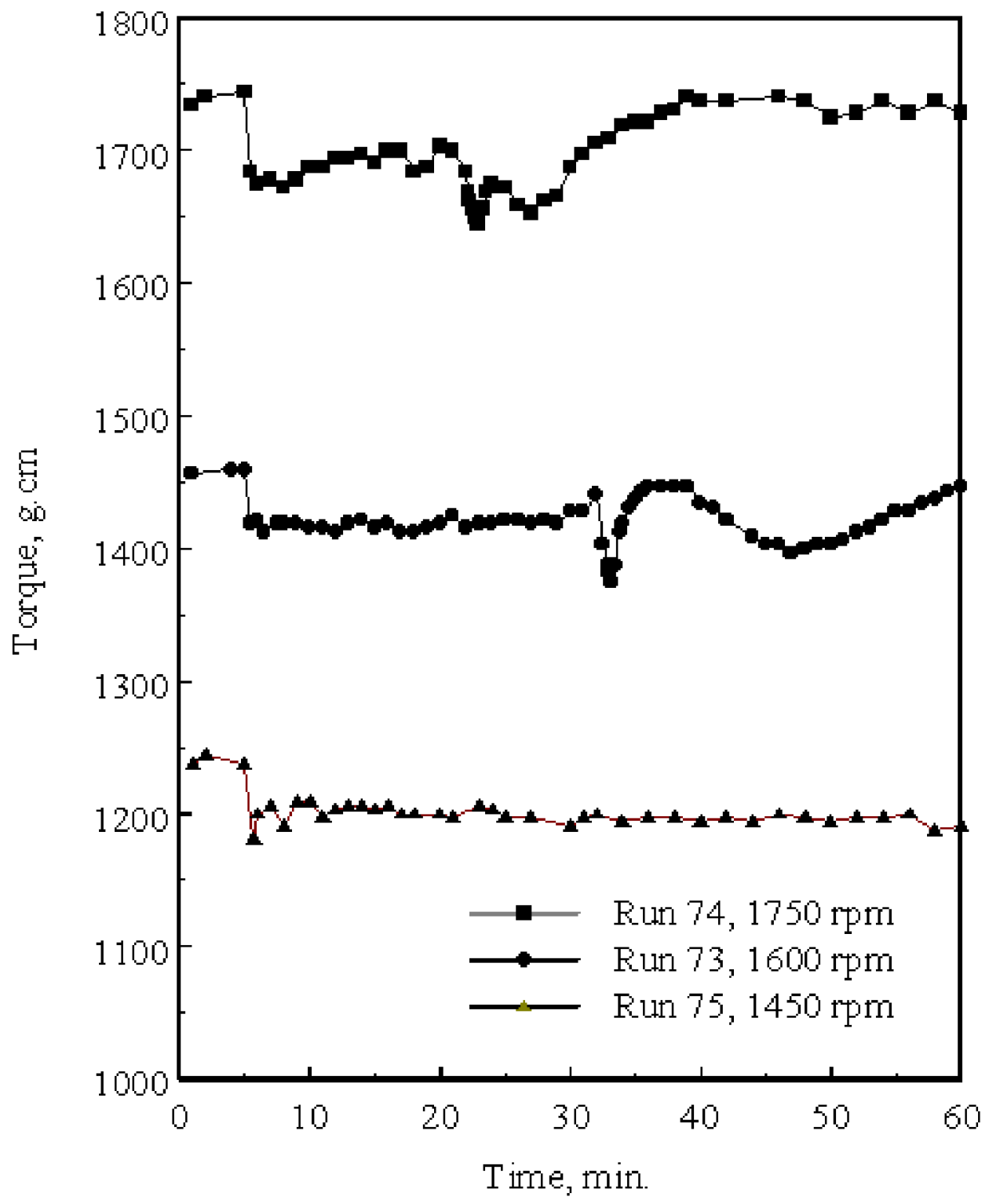

Figure 2. Results of three runs conducted with $30 \mathrm{w} / \mathrm{w} \%$ solids, $20 \mathrm{v} / \mathrm{w} \%$ oil, $4.5 \mathrm{v} / \mathrm{w} \%$ air, and different agitator speeds in $11.4 \mathrm{~cm}$ diameter tank. 


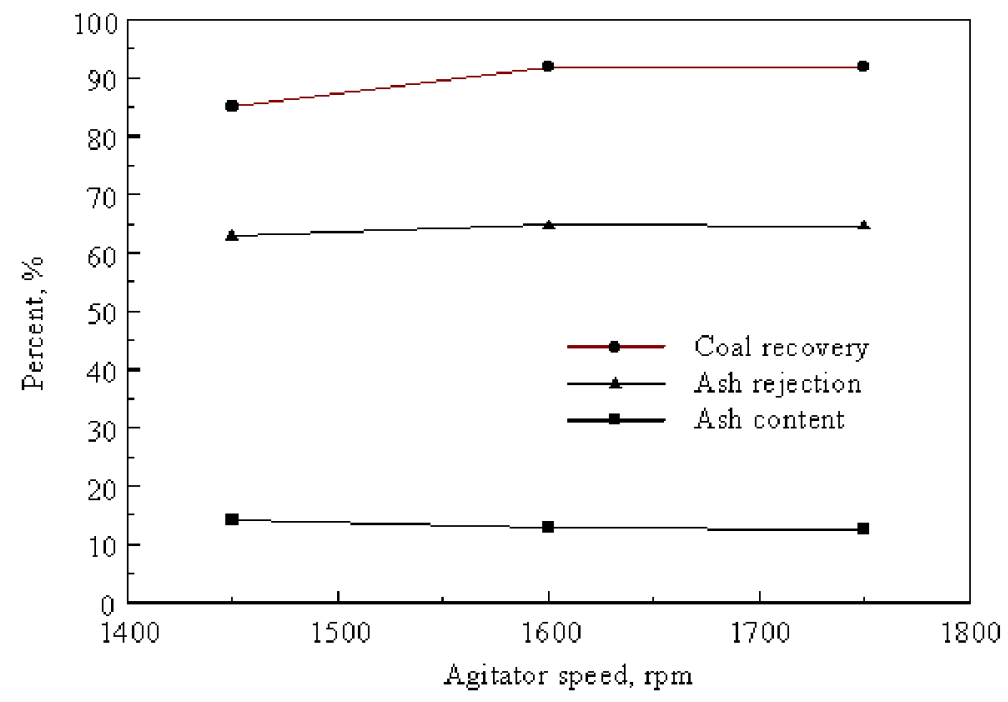

Figure 3. Effect of agitator speed on coal recovery, ash rejection, and product ash content for runs made with $30 \mathrm{w} / \mathrm{w} \%$ solids, 20 v/w\% oil, $18 \mathrm{v} / \mathrm{w} \%$ air, and $85 \mathrm{~min}$. treatment time.

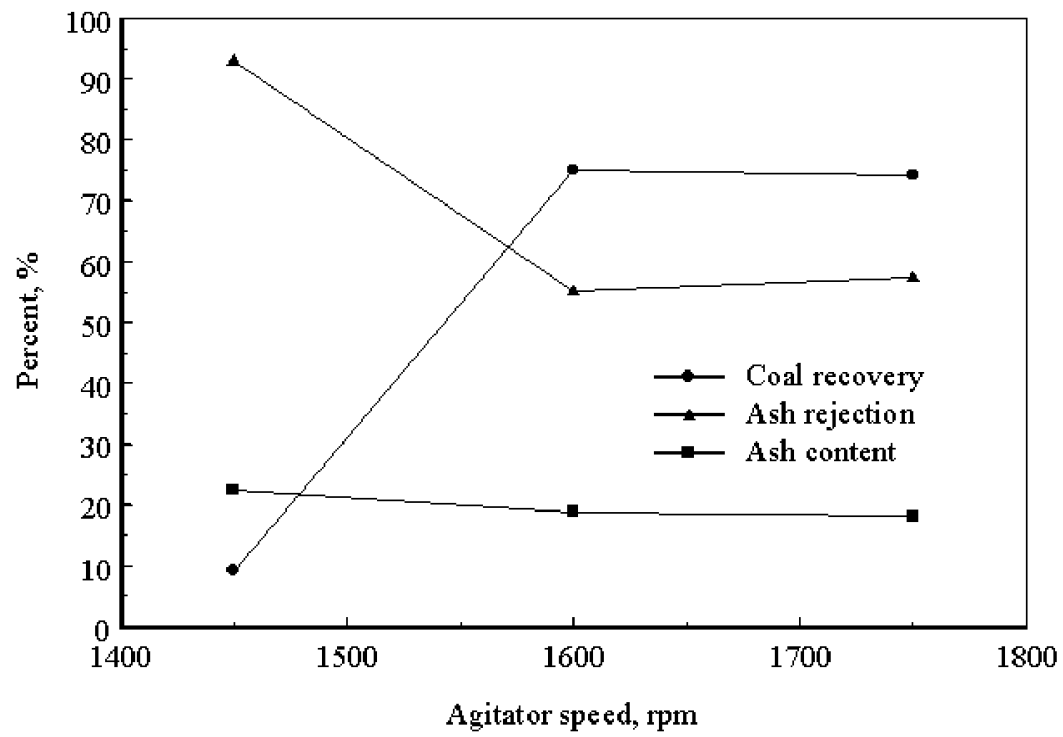

Figure 4. Effect of agitator speed on coal recovery, ash rejection, and product ash content for runs made with $30 \mathrm{w} / \mathrm{w} \%$ solids, 20 v/w\% oil, $4.5 \mathrm{v} / \mathrm{w} \%$ air, and $55 \mathrm{~min}$. treatment time. 
The results achieved with $20 \mathrm{v} / \mathrm{w} \%$ i-octane, $4.5 \mathrm{v} / \mathrm{w} \%$ air, and agitation time of 55 min. were much worse (see Figure 4). Since true agglomerates were not produced at $1450 \mathrm{rpm}$, coal recovery at this agitator speed was almost nonexistent. With an agitator speed of 1600 or $1750 \mathrm{rpm}$, coal recovery was $74-75 \%$ and ash rejection was $55-57 \%$. A comparison of these results with the previous set of results indicates that the reduced air concentration and treatment time were detrimental.

The reduced air concentration seemed to have a greater effect than the reduced time. This can be seen by comparing the results of runs 72,73 , and 80 which were conducted under the same conditions except for air concentration and treatment time. The differences in conditions and results are shown below.

$\begin{array}{llllc}\text { Run No. } & \text { Air, v/w\% } & \text { Time, min. } & \text { Ash Rej., } \% & \text { Coal Rec., \% } \\ 80 & 18 & 85 & 64.8 & 91.9 \\ 72 & 4.5 & 85 & 53.5 & 81.6 \\ 73 & 4.5 & 55 & 55.1 & 75.0\end{array}$

The above data indicate that the reduction in air concentration from 18 to 4.5 $\mathrm{v} / \mathrm{w} \%$ produced a relatively large drop in coal recovery and ash rejection, whereas the reduction in treatment time from 85 to 55 min. produced relatively small changes in coal recovery and ash rejection.

A combination of the results of runs 72 and 80 with those of run 64 conducted previously with $9 \mathrm{v} / \mathrm{w} \%$ air showed that coal recovery and ash rejection both increased gradually as air concentration increased (see Figure 5). 


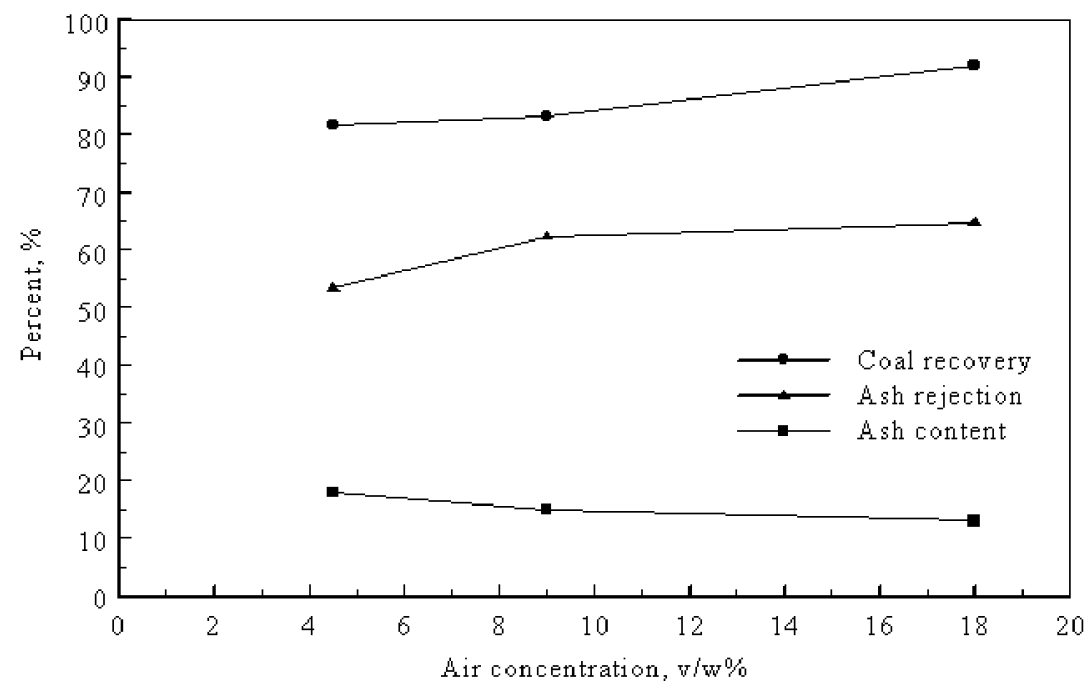

Figure 5. Effect of air concentration on coal recovery, ash rejection, and product ash content for runs made with $30 \mathrm{w} / \mathrm{w} \%$ solids, 20 $\mathrm{v} / \mathrm{w} \%$ oil, and $85 \mathrm{~min}$. treatment time using an agitator speed of $1600 \mathrm{rpm}$ in $11.4 \mathrm{~cm}$ diameter tank. 
The best results in the present series of runs were achieved in runs 82 and 83

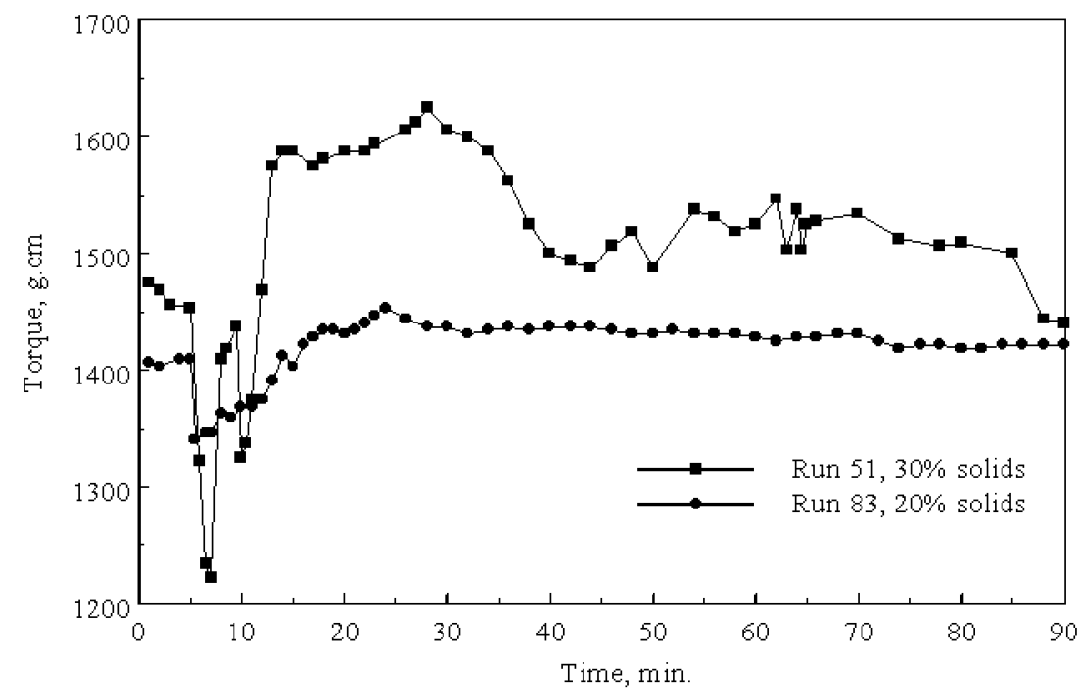

Figure 6. Results of two runs conducted with different solids concentrations while using $30 \mathrm{v} / \mathrm{w} \%$ oil, $9 \mathrm{v} / \mathrm{w} \%$ air, and an agitator speed of $1600 \mathrm{rpm}$ in the $11.4 \mathrm{~cm}$ diameter tank.

which were conducted with $20 \mathrm{w} / \mathrm{w} \%$ solids, $30 \mathrm{v} / \mathrm{w} \%$ i-octane, and $9 \mathrm{v} / \mathrm{w} \%$ air (see Table 1). For these runs, coal recovery was $96.6 \%$ and ash rejection was 76.5 and $77.6 \%$, respectively. Furthermore, the agglomerated product had the lowest ash content (i.e., $8.4 \mathrm{w} / \mathrm{w} \%$ ) of any of the runs. A comparison of these results with those obtained previously with a higher solids concentration is instructive. Shown below are the present results together with those of runs 51 and 55 made before under similar conditions except for solids concentration.

Run No. Speed, rpm Solids, w/w\% Size, mm Ash Rej., \% Coal Rec., $\%$

0.4-0.6

74.3

96.5

20

0.30

77.6

96.6 


$\begin{array}{llllll}55 & 1750 & 30 & 0.4-0.6 & 74.5 & 96.9 \\ 82 & 1750 & 20 & 0.25-0.30 & 76.5 & 96.6\end{array}$

It is apparent that coal recovery was virtually the same for all of the runs listed above, and therefore, it was essentially independent of both agitator speed and solids concentration for the given ranges of conditions. Ash rejection was slightly lower for the higher solids concentration than for the lower solids concentration, which was due to the presence of slightly more ash-forming mineral matter in the product recovered from the more concentrated suspensions. These suspensions also produced larger agglomerates than the less concentrated suspensions.

Solids concentration also affected agitator torque. Figure 6 shows the effect of solids concentration on agitator torque at $1600 \mathrm{rpm}$ and Figure 7 shows the effect at 1750 rpm. It can be seen that a higher solids concentration resulted in both a higher level of 


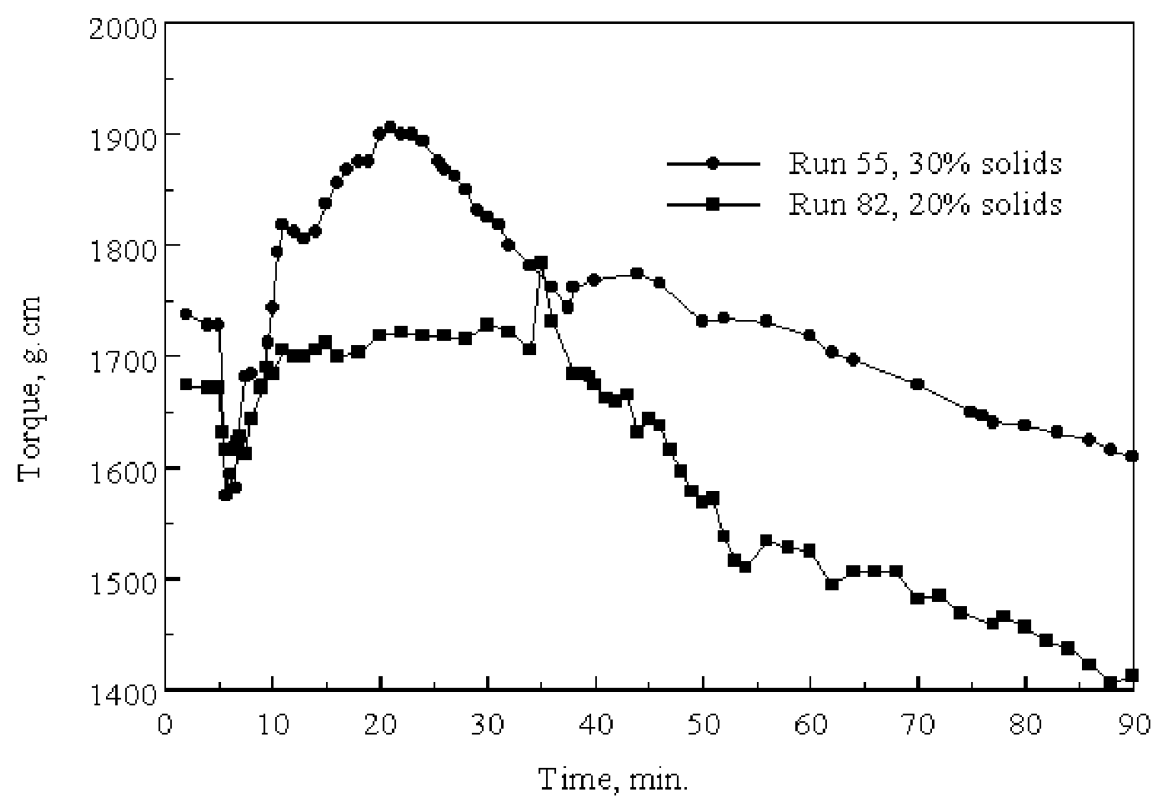

Figure 7. Results of two runs conducted with different solids concentrations while using $30 \mathrm{v} / \mathrm{w} \%$ oil, $9 \mathrm{v} / \mathrm{w} \%$ air, and an agitator speed of 1750 rpm in the $11.4 \mathrm{~cm}$ diameter tank.

torque and a greater variation in torque. The fluctuation in torque was especially great shortly after air was introduced into the more concentrated suspensions.

\section{CONCLUSIONS}

The results presented above augment the results of previous agglomeration tests and provide a clearer picture of the effects of various system parameters on coal recovery and ash rejection when finely ground Pittsburgh No. 8 coal is agglomerated with i-octane. For the range of variables investigated, coal recovery and ash rejection both increased with increases in air concentration and agitator speed. The rate of fluctuation of agitator torque over time suggests that the rate of agglomeration increased with an 
increase in air concentration. An increase in solids concentration from 20 to $30 \mathrm{w} / \mathrm{w} \%$ had no effect on coal recovery when neither treatment time nor other parameters were limiting. However, ash rejection decreased slightly because the ash content of the agglomerated product was slightly higher.

\section{REFERENCES}

1. T. D. Wheelock and M. Shen, "Development of a Gas-Promoted Oil Agglomeration Process," Quarterly Technical Progress Report, April 1, 1996, to June 30, 1996, Chemical Engineering Department and Center for Coal and the Environment, Iowa State University, Ames, Iowa.

2. T. D. Wheelock and M. Shen, "Development of a Gas-Promoted Oil Agglomeration Process," Quarterly Technical Progress Report, July 1, 1996, to September 30, 1996, Chemical Engineering Department and Center for Coal and the Environment, Iowa State University, Ames, Iowa.

3. T. D. Wheelock, J. Drzymala and M. Shen, "Development of a Gas-Promoted Oil Agglomeration Process," Quarterly Technical Progress Report, October 1, 1995, to December 31, 1995, Chemical Engineering Department and Center for Coal and the Environment, Iowa State University, Ames, Iowa. 

